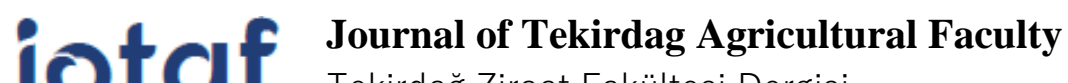

\section{Yumurtlamanın Son Dönemindeki Yumurtacı Tavukların Rasyonlarına Bor (Orthoborik Asit) İlavesinin Serum Lipid ve Protein Profili Üzerine Etkisi}

The Effects of Boron (Orthoboric Acid) Supplementation into Diets on Serum Lipid and Protein Profiles of Hens During Late Laying Period

\section{Hacer KAYA ${ }^{1}$, Muhlis MACIT ${ }^{2}$}

\section{Öz}

Yumurtacı tavuk rasyonlarına Bor ilavesinin serum parametreleri üzerine etkisini tespit etmek amaciyla yürütülen çalışmada, 62 haftalık 288 adet Lohman yumurtacı ticari hibrit tavuklar bazal yem 0 (B0), 50 (B50), 75 (B75) ve 150 (B150) mg/kg B içeren dört farklı rasyonla 12 hafta boyunca yemlenmişlerdir. Araştırma 18 tekerrürlü olarak yürütülmüş ve her bir tekerrürde 4 adet tavuk bulundurulmuştur. Çalışma boyunca 16 saat aydınlatma programı uygulanmış, yem ve su ad-libitum olarak verilmiştir. Serum lipid bileşenlerinden diaçilgliserol ve hidrokarbon+kolesterol esteri düzeylerine muamelenin etkisi önemsiz olurken $(\mathrm{P}>0.05)$, polarlipid, triaçilgliserol $(\mathrm{P}<0.05)$ ve kolesterol $(\mathrm{P}<0.01)$ düzeylerine B'nin etkisi önemli bulunmuştur. Rasyonlarına 75 ve $150 \mathrm{mg} / \mathrm{kg} \mathrm{B}$ ilave edilen grupların serum lipid peroksidasyonu değerleri diğer gruplardan daha düşük olmuştur. Rasyona B ilavesi farklı moleküler ağırlıktaki proteinleri farklı seviyelerde etkilemiştir. Sonuç olarak, yumurtacı tavukların yemine farklı miktarlarda B ilavesinin serum lipid peroksidasyonu ile serum lipid ve serum protein profilini önemli derecede etkilediği tespit edilmiştir. Fakat, söz konusu parametreler üzerine B'nin etkisiyle ilgili değişiklikleri netleştirmek için daha fazla araştırma yapılması gerektiği kanaatine varılmıştır.

Anahtar Kelimeler: serum, lipid profili, protein profili, peroksidasyon

\begin{abstract}
This study was carried out to determine the effects of boron addition into the diets on serum parameters of hens. A total of 288 Lohman laying commercial hybrid chickens of 62 weeks were fed for 12 weeks with four different rations containing basal feed 0 (B0), 50 (B50), 75 (B75) and 150 (B150) $\mathrm{mg} / \mathrm{kg}$ B. Each group was replicated in 18 cages, four hens per cage. During the study, 16 hours lighting program was applied, feed and water were given as ad-libitum. The effect of boron supplementation was not significant on the rates of diacylglycerol and hydrocarbon+cholesterol esters $(\mathrm{P}>0.05)$ but the rates of polarlipid, triacylglycerol $(\mathrm{P}<0.05)$, and serum total cholesterol $(\mathrm{P}<0.01)$ were found significant. Lipid peroxidation values of groups fed with diets including 75 and $150 \mathrm{mg} / \mathrm{kg}$ B were determined lower than others. Addition of ration B affected different molecular weight proteins at different levels. In conclusion, it has been determined that the addition of B at different levels into the diets of laying hens during late laying period significantly influenced the serum lipid peroxidation, serum lipid and serum protein profile, but further researches are needed to clarify the changes related to the effects of $\mathrm{B}$ addition into diets on mentioned parameters of laying hens.
\end{abstract}

Keywords: serum, lipid profile, protein profile, peroxidation

\footnotetext{
1*Sorumlu Yazar/Corresponding Author: Hacer Kaya, Gümüşhane Üniversitesi, Şiran Mustafa Beyaz Meslek Yüksek Okulu, Veterinerlik Bölümü, 29700, Gümüşhane. E-mail: hacerkaya @ gumushane.edu.tr (iD) OrcID: 0000-0001-9024-8525

${ }^{2}$ Muhlis Macit, Atatürk Üniversitesi, Ziraat Fakültesi, Zootekni Bölümü, Erzurum. E-mail: mmacit@atauni.edu.tr (iD OrcID: 0000-0002-5055-1156 Atıf/Citation: Kaya, H., Muhlis, M. Yumurtlamanın son dönemdeki yumurtacı tavukların rasyonlarına bor (orthoborik asit) ilavesinin serum lipid ve serum protein üzerine etkisi. Tekirdağ Ziraat Fakültesi Dergisi, 17(1), xx-xx.

*Bu çalışma Doktora tezinden özetlenmiştir.

CBu çalışma Tekirdağ Namık Kemal Üniversitesi tarafindan Creative Commons Lisansı (https://creativecommons.org/licenses/by-nc/4.0/) kapsamında yayınlanmıştır. Tekirdağ 2019
} 


\section{Extended Summary}

Rations should be prepared carefully in order to meet the mineral needs of poultry in an adequate and balanced manner. Essential minerals are defined as the minerals that must be taken with the ration at the determined levels in order to obtain the expected performance from poultry. Some specific clinical and metabolic symptoms occur in animals when essential minerals are not taken in sufficient amounts by ration. However, when essential minerals are added to the ration, both the occurrence of these symptoms can be prevented and the disorders formed can be treated (Yazgan et al., 2007). While the sensitivity to protein, metabolic energy and macro element levels are generally shown in the preparation of rations, due to the very complex bioavailability of micro elements and the lack of sufficient research on the subject, the level of these in the ration is not paid necessary attention (Forbes, 1984). The needs of animals for a micro element and their tolerance to the amount of that element in the ration vary depending on factors such as animal species, age, physiological status, form of the element in the ration and bioavailability, research duration and experimental parameters (Ammerman et al., 1995). In recent years, studies on the problems and precautions to be taken due to various micro element deficiency in poultry have gained momentum. In cereals commonly used in poultry feeds, there are micro-element deficiencies that develop due to various reasons and copper, manganese, zinc and selenium can be given as an example (Okuyan, 1997). Boron (B), one of the micronutrients, has long been known to be an essential element for plants, but it is not yet clear whether it is essential for humans and animals. However, since the beginning of the 1980s, although there have been studies showing that B may be essential in human and animal studies biochemical function or functions have not been fully determined yet (Nielsen, 1997). An important part of the research on B is on industrial studies. Research on the effects of B on animal nutrition and human health has been started in recent years (Eren, 2004). Studies have shown that boron affects the use and metabolism of energy substitutes (macro elements, triglycerides, glucose etc.) involved in the fulfillment of vital functions in the body, and generally changes beneficial the functions and compositions of various body systems such as the brain, skeleton, and immune system (Hunt, 1989; Hunt and Herbel 1991; Wilson and Ruzzler 1998; Eren et al., 2004). It is stated that especially fruits, fiber vegetables, stem and shells are rich in B content compared to animal products and cereals (such as corn, rice and wheat) (Hunt et al., 1991). The fact that the majority of poultry rations are made from cereals and the B content of cereal grains is insufficient, exposes poultry inadequate feeding in terms of element B (Hunt, 2006). It is of high quality and large amounts of B and compounds in Turkey (Yildiz et al., 2008). Therefore, the use of B and its compounds, especially in poultry nutrition, is important for the national economy.

This study was carried out to determine the effects of B addition into the diets on serum parameters of hens. A total of 288 Lohman laying commercial hybrid chickens of 62 weeks were fed for 12 weeks with four different rations containing basal feed 0 (B0), 50 (B50), 75 (B75) and 150 (B150) $\mathrm{mg} / \mathrm{kg}$ B. Each group was replicated in 18 cages, four hens per cage. During the study, 16 hours lighting program was applied, feed and water were given as ad-libitum. The effect of $\mathrm{B}$ supplementation was not significant on the rates of diacylglycerol and hydrocarbon+cholesterol esters $(\mathrm{P}>0.05)$ but the rates of polarlipid, triacylglycerol $(\mathrm{P}<0.05)$, and serum total cholesterol $(\mathrm{P}<0.01)$ were found significant. Lipid peroxidation values of groups fed with diets including 75 and $150 \mathrm{mg} / \mathrm{kg}$ B were determined lower than others. Addition of ration B affected different molecular weight proteins at different levels. In conclusion, it has been determined that the addition of B at different levels into the diets of laying hens during late laying period significantly influenced the serum lipid peroxidation, serum lipid and serum protein profile, but further researches are needed to clarify the changes related to the effects of B addition into diets on mentioned parameters of laying hens. 
Kanatlı hayvanların mineral ihtiyaçlarının yeterli ve dengeli olarak sağlanabilmesi için rasyonlarının ihtiyaçlarını karşılayacak şekilde hazırlanması gerekmektedir. Kanatlı hayvanlardan beklenen performansın elde edilebilmesi için belirlenen düzeylerde rasyonla mutlaka alınması gereken mineraller "esansiyel mineral" olarak tanımlanmaktadır. Esansiyel mineraller rasyonla yeteri miktarda alınmadıklarında hayvanlarda özel bazı klinik ve metabolik semptomlar meydana gelmektedir. Ancak, rasyona ilave edildiklerinde bu belirtilerin meydana gelişleri önlendiği gibi oluşmuş bozukluklar da tedavi edilebilmektedir (Yazgan ve ark., 2007).

Rasyon hazırlamada genelde protein, metabolik enerji ve makro elementlere gereken hassasiyet gösterilirken, mikro elementlerin biyoyararlılığının çok karmaşık olması ve konu ile ilgili yeterli araştırma olmaması nedeniyle mikro elementlerin rasyondaki düzeyine gereken özen gösterilmemektedir (Forbes, 1984). Hayvanların bir mikro elemente duydukları ihtiyaç ve o mikro elementin rasyondaki miktarına karşı toleransları; hayvanın türü, yaşı, fizyolojik durumu, elementin rasyondaki formu ve biyolojik kullanılabilirliği, araştırma süresi, deneme parametreleri gibi faktörlere bağlı olarak değişmektedir (Ammerman ve ark., 1995).

Kanatlı hayvanlarda çeșitli mikro element yetersizliğine bağlı sorunlar ve alınması gereken önlemler konusundaki çalışmalar son yıllarda hız kazanmıştır. Kanatlı hayvan yemlerinde yaygın olarak kullanılan tahıllarda, çeşitli nedenlere bağlı olarak gelişen mikro element yetersizlikleri söz konusu olup; bakır, mangan, çinko ve selenyum buna örnek olarak verilebilir (Okuyan, 1997).

Mikro besin elementlerinden biri olan Bor'un (B) bitkiler için esansiyel bir element olduğu uzun zamandan beri bilinmekte ise de insanlar ve hayvanlar için esansiyel olup olmadığı henüz kesinlik kazanmamıştır. Bununla beraber 1980'li yılların başından itibaren insan ve hayvanlarda yapılan çalışmalarda B'nin esansiyel olabileceğini gösteren bulgular elde edilmesine rağmen biyokimyasal fonksiyonu ya da fonksiyonları tam olarak henüz belirlenmemiştir (Nielsen, 1997).

Bor ile ilgili araştırmaların önemli bir bölümü endüstriyel çalışmalar üzerine olup, hayvan besleme ve insan sağlığına etkilerini inceleyen araştırmalar son yıllarda yapılmaya başlanmıştır (Eren, 2004). Yapılan çalışmalar B'nin, vücutta hayati fonksiyonların yerine getirilmesinde görev yapan enerji sübsratlarının (makro elementler, trigliserid, glukoz gibi) kullanım ve metabolizmalarını etkilediği, beyin, iskelet ve bağışıklık sistemi gibi çeşitli vücut sistemlerinin fonksiyonlarını ve kompozisyonlarını genellikle faydalı yönde değiştirdiği bildirilmiştir (Hunt, 1989; Hunt ve Herbel 1991; Wilson ve Ruzzler 1998; Eren ve ark., 2004). Bitkisel kökenli yiyeceklerin; özellikle meyveler, lifli sebzeler, sap ve kabukların hayvansal ürünlere ve tahıllara (mısır, pirinç ve buğday) oranla B bakımından daha zengin olduğu ifade edilmektedir (Hunt ve ark., 1991). Kanatlı rasyonlarının büyük çoğunluğunun tahıllardan oluşturulması ve tahıl tanelerinin de B bakımından yetersiz olması, kanatlıları B elementi bakımından yetersiz besleme ile karşı karşıya bırakmaktadır (Hunt, 2006). Türkiye'de kaliteli ve bol miktarda bulunan B ve bileşiklerinin (Yıldız ve ark., 2008) özellikle kanatlı hayvan beslemede kullanılması ile olası verim artışı ülke ekonomisi açısından önem arz etmektedir.

Naghii ve Samman (1993), rat içme sularına, Naghii ve Samman (1997) ise rat rasyonlarına B ilavesinin serum total kolesterolü etkilemediği, serum triaçilgliserol değerlerini ise azalttığını $(\mathrm{P}<0.05)$ bildirmişlerdir. Eren ve ark. (2006), Japon bıldırcını rasyonlarına 0, 10, 60, $120 \mathrm{ve} 240 \mathrm{mg} / \mathrm{kg}$ B ilave ederek serum lipid değerlerini inceledikleri çalışmada, rasyona ilave edilen B'nin bütün seviyelerinde serum trigliserid ve total kolesterol düzeylerinin düştüğü $(\mathrm{P}<0.05)$ rapor edilmiştir. Eren ve Uyanık (2007), yumurtacı tavuk rasyonlarına B ilavesinin $(0,5,10,50,100,200$ ve $400 \mathrm{mg} / \mathrm{kg})$ bazı serum parametrelerine etkilerini inceledikleri çalışmada, total kolesterol düzeylerinin ilave B seviyelerinin tamamında, serum trigliserid düzeylerinin ise $5 \mathrm{mg} / \mathrm{kg}$ B ilave edilen grup hariç diğer tüm gruplarda azaldığını $(\mathrm{P}<0.05)$ tespit etmişlerdir. Sonuç olarak, serum biyokimyasal parametrelerini etkilemede $5 \mathrm{mg} / \mathrm{kg}$ B ilavesinin yeterli olduğu kanaatine varmışlardır. Olgun (2011), 0, 60, $120 \mathrm{ve} 240 \mathrm{mg} / \mathrm{kg}$ seviyelerinde B içeren rasyonlarla beslenen yumurtacı tavuklarda B ilavesinin deneme ortası (56. gün) ve sonu (112. gün) serum trigliserid ve total kolesterol düzeylerini azalttığını tespit etmiştir $(\mathrm{P}<0.05)$. Armstrong ve ark. (2000), domuz rasyonlarına, Kurtoğlu ve ark. (2005) ise etlik piliç rasyonlarına $0,5 \mathrm{ve} 15 \mathrm{mg} / \mathrm{kg}$ seviyelerinde B ilavesinin serum total kolesterol ile serum trigliseridi $(\mathrm{P}<0.05)$ artırdığını bildirmişlerdir. Armstrong ve Spears (2001), domuzları 0, $5 \mathrm{ve} 15 \mathrm{mg} / \mathrm{kg}$ seviyelerinde B içeren; Mızrak ve Ceylan (2009), yumurtacı tavukları $25,50 \mathrm{ve} 75 \mathrm{mg} / \mathrm{kg}$ B sağlayacak şekilde organik veya inorganik B içeren; Şimşek (2011), etlik piliçleri 0, 100, $200 \mathrm{ve} 400 \mathrm{mg} / \mathrm{kg}$ seviyelerinde B içeren rasyonlarla besledikleri çalışmalarda, ilave B'nin serum total kolesterol ve trigliserid düzeyleri üzerine etkili olmadığını belirlemişlerdir. Yumurtacı tavuklarda B'nin toksik seviyesi $300 \mathrm{mg} / \mathrm{kg}$ olarak bildirilmiş olmasına rağmen (Underwood ve Suttle, 1999), kanatlı hayvanların B ihtiyacı tam olarak belirlenmemiş̧tir. 
Mevcut çalışma; yumurtlamanın üçüncü döneminde (62-82 haftalık yaş grubunda ) bulunan yumurtacı tavuklarda rasyona $0,50,75$ ve $150 \mathrm{mg} / \mathrm{kg}$ dozlarında \%99.995 oranında saf Bor'un yaygın kaynağı olan Ortoboric Asit ilavesinin serum lipid bileşenleri, serum protein profili ve serum lipid peroksidasyonu üzerine etkilerini belirlemek amaciyla yürütülmüştür.

\section{Materyal ve Yöntem}

\section{Hayvan materyali}

Çalışmanın hayvan materyalini, Atatürk Üniversitesi Ziraat Fakültesi Araştırma ve Uygulama Çiftliği Tavukçuluk Şubesinde yetiştirilen ve yumurtlamanın üçüncü döneminde (62-82 haftalar arası) bulunan 288 adet 62 haftalık yaşta Lohman beyaz yumurtacı tavuk oluşturmuştur.

\section{Yem materyali}

Araştırmanın yem materyalini, özel bir yem fabrikasından temin edilen, bileşimi ve kimyasal kompozisyonu Çizelge 1'de verilen kafes yumurtacı tavuk yemi oluşturmuştur.

Çizelge 1. Bazal Yemin Bileşimi ve Besin Madde Kompozisyonu

Table 1. Basal Food Composition and Nutrient Composition Used in Research

\begin{tabular}{|c|c|c|c|}
\hline Yem Ham Mad. & $\%$ & Kimyasal Kompozisyon & $\%$ \\
\hline Misir & 29.90 & Kuru Madde & 88.00 \\
\hline Buğday & 40.00 & Ham Protein & 16.00 \\
\hline $\begin{array}{l}\text { Ayçiçeği } \quad \text { Tohumu } \\
\text { Küspesi }\end{array}$ & \multicolumn{2}{|c|}{ Küspesi } & 7.00 \\
\hline Soya Fasulyesi Küspesi & 15.00 & Ham Kül & 13.00 \\
\hline Yağ & 1.00 & HCL'de Çözünmeyen kül & 1.00 \\
\hline Tuz & 0.30 & $\mathrm{NaCl}$ & 0.35 \\
\hline DCP 18 & 1.00 & Lisin & 0.65 \\
\hline Kalsiyum Karbonat & 8.00 & Metiyonin & 0.32 \\
\hline \multirow[t]{5}{*}{ Premiksler } & 0.20 & Sistin & 0.30 \\
\hline & & Kalsiyum & 3.50 \\
\hline & & Fosfor & 0.60 \\
\hline & & Sodyum & 0.16 \\
\hline & & $\mathrm{ME}, \mathrm{kcal} / \mathrm{kg}$ yem & 2650 \\
\hline
\end{tabular}

Her 2 kg'da: 12.000.000 IU Vitamin A, 2.400.000 IU Vitamin $\mathrm{D}_{3}, 30.000 \mathrm{mg}$ Vitamin E, $4.000 \mathrm{mg}$ Vitamin $\mathrm{K}_{3}, 3.000 \mathrm{mg}$ Vitamin $\mathrm{B}_{1}, 7.000 \mathrm{mg}$ Vitamin $\mathrm{B}_{2}, 25.000 \mathrm{mg}$ Niasin, $10.000 \mathrm{mg}$ Cal-D-Pantotenat, $5.000 \mathrm{mg}$ Vitamin $\mathrm{B}_{6}, 15 \mathrm{mg}$ Vitamin $\mathrm{B}_{12}, 45 \mathrm{mg}$ D-Biotin, $1.000 \mathrm{mg}$ Folik Asid, $125.000 \mathrm{mg}$ Kolin Klorit, $2.000 \mathrm{mg}$ Kantaksantin, $5.00 \mathrm{mg}$ Apo-karotenoik asit ester, $50.000 \mathrm{mg}$ Vitamin C, $80.000 \mathrm{mg}$ Manganez, $60.000 \mathrm{mg}$ Demir, $60.000 \mathrm{mg}$ Çinko, $5.000 \mathrm{mg}$ Bakır, $2.00 \mathrm{mg}$ Kobalt, $1.000 \mathrm{mg}$ İyot, $150 \mathrm{mg}$ Selenyum.

Çalışmada kullanılan rasyonlar, Atatürk Üniversitesi Ziraat Fakültesi Araştırma ve Uygulama Çiftliği Hayvancılık Şubesi'ndeki Yem Ünitesi'nde, ETİ Maden İşletmeleri'nden temin edilmiş olan katı haldeki Bor (düşük sülfatlı borik asit $\mathrm{B}_{2} \mathrm{O}_{3}: \mathrm{B}_{2} \mathrm{O}_{3}$ ppm \%56.30, $\mathrm{SO}_{4}$ ppm \%110, Fe ppm \%4.69, CI ppm \%5.92) bazal yeme farklı miktarlarda $(0,50,75 \mathrm{ve} 150 \mathrm{mg} / \mathrm{kg} \mathrm{B})$ homojen bir şekilde karıştırılarak hazırlanmıştır. B'nin rasyona homojen bir şekilde karışımını sağlamak için, önce her bir deneme grubuna ait bir miktar yem ile o grubun 
rasyonuna katılacak B, mikserde iyi bir şekilde karıştırılarak bir ön karma oluşturulmuş, daha sonra bu ön karma azar azar rasyona ilave edilmiştir.

\section{Yöntem}

Rasyonların kimyasal analizleri (kuru madde, ham protein, ham yağ, ham kül, ADF, NDF) Atatürk Üniversitesi Ziraat Fakültesi Zootekni Bölümü Yem Analiz Laboratuvarı'nda Weende analiz yöntemine göre belirlenmiş (AOAC, 1990) ve Çizelge 2'de sunulmuştur.

Çizelge 2. Araştırmada Kullanılan Karma Yemlerin Laboratuvar Analiz Sonuçları

Table 2. Laboratory Analysis Results of Mixed Feeds Used in Research

\begin{tabular}{|c|c|c|c|c|}
\hline Gruplar & B0 & B50 & B75 & B150 \\
\hline Kuru Madde & 88.9 & 89.2 & 89.0 & 88.8 \\
\hline Ham Protein & 16.2 & 16.4 & 16.0 & 17.1 \\
\hline Ham Yağ & 3.0 & 3.1 & 3.0 & 2.9 \\
\hline Ham Kül & 11.4 & 12.0 & 11.7 & 12.4 \\
\hline $\mathrm{ADF}$ & 7.6 & 7.5 & 7.6 & 7.9 \\
\hline $\mathrm{NDF}$ & 24.4 & 21.4 & 20.2 & 26.9 \\
\hline $\mathrm{ME}^{*}$ & 2650 & 2641 & 2636 & 2640 \\
\hline
\end{tabular}

*Hesaplanarak bulunmuştur (TSE, 1991).

Bazal yem ve rasyonların Bor elementi seviyelerini belirlemek için yem örnekleri, Atatürk Üniversitesi Ziraat Fakültesi Toprak Bölümü Laboratuvarı'nda 40 bar basınca dayanıklı mikrodalga yaş yakma ünitesinde (speedwave MWS-2 Berghof productts + Instruments Harresstr.1. 72800 Enien Gernmany) yakıldıktan sonra Atomik Emüsyon Spektrofotometre cihazı (AX-ICP, Varian Vista) kullanılmıştır (Mertens, 2005). Çalışmada kullanılan yemlerin Bor içeriği B0, B50, B75 ve B150 grupları için sırasıyla 2.9, 52.8, 77.4 ve $150.2 \mathrm{mg} / \mathrm{kg}$ olarak tespit edilmiştir.

Deneme grupları; 18 tekerrürlü ve her tekerrürde 4 hayvan olmak üzere, her bir grup için 72 tavuk konularak toplam 288 hayvandan oluşturulmuştur. Deneme gruplarından 1. grup (kontrol grubu) bazal yemle (B0), 2. grup bazal yeme $50 \mathrm{mg} / \mathrm{kg} \mathrm{B} \mathrm{(B50),} \mathrm{3.} \mathrm{grup} \mathrm{bazal} \mathrm{yeme} 75 \mathrm{mg} / \mathrm{kg} \mathrm{B} \mathrm{(B75)} \mathrm{ve} \mathrm{4.} \mathrm{grup} 150 \mathrm{mg} / \mathrm{kg} \mathrm{B}$ (B150) ilave edilmiş rasyonlarla beslenmişlerdir. Deneme yemlerine alıştırma periyodu (1 hafta) hariç hayvanlar toplam 12 hafta süreyle denemeye alınmışlardır. Hayvanlara yem ve su ad-libutum olarak verilmiştir. Deneme süresi boyunca 16 saatlik günlük aydınlatma programı flüoresan lamba ile sağlanmıştır. Hayvanların deneme süresince bakım ve beslenmeleri araştırmanın yürütüldüğü kümeste üç katlı batarya tipi kafeslerde gerçekleştirilmiştir. Kafeslerin herbirine 4 tavuk ve birer adet nippel başlıklı suluk konulmuştur.

Denemenin sonunda yem verilmeden önce her gruptan rastgele 10 hayvan seçilerek, kanat venasından (vena cutenea ulnaris) içinde pıhtılaşma faktörü bulunan 10 ml'lik cam tüplere yaklaşı $7 \mathrm{ml}$ kan alınmıştır. Kan örnekleri Atatürk Üniversitesi Veteriner Fakültesi Biyokimya ABD Laboratuarı'nda $+4^{\circ} \mathrm{C}$ 'de 5 dakika süre ile 3000 x G'de santrifüj edilerek serum kısmı ayrılmış ve analiz edilene kadar $-82^{\circ} \mathrm{C}^{\prime} \mathrm{de}$ saklanmıştır. Serum lipid ve protein profilini tespit etmek için; homojenize edilmiş serum tüpleri analizden bir gün önce dondurucudan çıkartılarak çözülmeleri beklenmiştir. Atatürk Üniversitesi Veteriner Fakültesi Biyokimya ABD Laboratuvarı'nda Yüksek Performanslı İnce Tabaka Kromatografi (YPİTK) metodu ile serum lipid profil analizi (Sherma, 2003), sodyum dodesil sülfat poliakrilamid jel elektroforez (SDS-PAGE) metodu ile de serum protein profil analizi gerçekleştirilmiştir (Laemmli, 1970). Serum protein analiz sonucunda her bir protein bandının total protein konsantrasyonu içindeki "bireysel yüzde" değerleri kullanılarak, Lowry yöntemiyle total protein miktarları hesaplanmış olan örneklerde "g" olarak bireysel protein miktarları belirlenmiştir (Lowry, 1951). Lipid peroksidasyonu için, $250 \mu \mathrm{l}$ serum homojenatı üzerine $2.25 \mathrm{ml}$ renk ayıracı eklenerek kaynar su banyosunda 20 dakika süreyle kaynatılmıştır. Süre sonunda soğuk suda soğutularak 
2000xG'de 5 dk süreyle santrifüj edildikten sonra tüpler santrifüjden çıkartılmış ve $200 \mu$ l süpernatant alınarak 532 nanometre dalga boyuna ayarlanmış spektrofotometrede absorbans değeri köre karşı okunarak, serum malondialdehit (MDA) düzeyleri (Placer ve ark., 1966) aşağıdaki formüle göre hesaplanmıştır.

$$
\text { Serum MDA düzeyi }(\mathrm{Nmol} / \mathrm{g})=35.61 \times \text { Optik Dansite }
$$

\section{İstatistik analiz}

Deneme süresince elde edilen ham veriler SPSS 10.01 (SAS, 1996) paket programı yardımıla GLM prosedürünün tekrarlamalı gözlem yöntemine göre analize tabi tutulmuştur. Gruplar arası varyans analizinde önemlilik kontrolü için de Duncan (1995) çoklu karşılaştırma testinden yararlanılmıştır.

\section{Bulgular}

Yumurtacı tavuk rasyonlarına farklı seviyelerde ilave edilen B'nin serum lipid bileşenlerinden diaçilgliserol ve hidrokarbon+kolesterol esteri düzeylerine etkisi önemsiz olurken, polarlipid, triaçilgliserol $(\mathrm{P}<0.05)$ ve kolesterol düzeylerine etkisi önemli $(\mathrm{P}<0.01)$ bulunmuştur.

Çizelge 3. Rasyona İlave Edilen Bor Seviyelerinin yumurtacı Tavuklarda Serum Lipid Bileşimi (\%) ve Lipid Peroksidasyonuna Etkisi(nmol/g doku)

Table 3. Effect of Boron (Ortoboric Acid) Levels Added to Ration on Serum Lipid Composition (\%) and Lipid Peroxidation in Laying Hens

\begin{tabular}{cllllll}
\hline Grp & Polarlipid & Diaçilgliserol & Triaçilgliserol & Kolesterol & H+KE & \\
& & & & & \\
\hline B0 & $14.9 \pm 0.5 \mathrm{~b}$ & $2.6 \pm 0.4$ & $61.0 \pm 1.7 \mathrm{ab}$ & $13.0 \pm 0.6 \mathrm{a}$ & $8.8 \pm 2.3$ & $3.7 \pm 0.4 \mathrm{ab}$ \\
B50 & $15.7 \pm 1.2 \mathrm{~b}$ & $2.1 \pm 0.3$ & $60.9 \pm 1.9 \mathrm{ab}$ & $12.5 \pm 0.6 \mathrm{ab}$ & $8.8 \pm 1.7$ & $3.9 \pm 0.4 \mathrm{a}$ \\
B75 & $14.9 \pm 1.1 \mathrm{~b}$ & $2.2 \pm 0.3$ & $62.9 \pm 1.4 \mathrm{a}$ & $12.1 \pm 0.4 \mathrm{bc}$ & $7.9 \pm 1.3$ & $3.5 \pm 0.2 \mathrm{~b}$ \\
B15 & $17.7 \pm 3.4 \mathrm{a}$ & $2.0 \pm 0.5$ & $59.3 \pm 3.3 \mathrm{~b}$ & $11.6 \pm 0.7 \mathrm{c}$ & $9.5 \pm 1.9$ & $3.4 \pm 0.4 \mathrm{~b}$ \\
Ort & $15.8 \pm 2.1$ & $2.1 \pm 0.4$ & $61.0 \pm 2.5$ & $12.3 \pm 0.8$ & $8.8 \pm 1.8$ & $3.6 \pm 0.4$ \\
P & 0.020 & 0.571 & 0.026 & 0.000 & 0.425 & 0.017 \\
\hline
\end{tabular}

H+KE: Hidrokarbon+Kolesterol Esteri, LP: Lipid Peroksidasyonu (nmol/gdoku),

a, b, c: Aynı sütundaki farklı harfle gösterilen ortalamalar arasındaki fark önemlidir.

Yumurtacı tavuk rasyonlarına ilave edilen $0,50,75$ ve $150 \mathrm{mg} / \mathrm{kg}$ düzeylerindeki B'nin serum lipid bileşenlerinden olan diaçilgliserol (\%) oranları B gruplarına göre sırasıyla 2.6, 2.1, 2.2 ve 2.0 olarak belirlenmiş olup en düşük diaçilgliserol oranı \%2.0 ile B150 grubunda, en yüksek diaçilgliserol oranı \%2.6 ile B0 grubunda tespit edilmiştir. Gruplar arasındaki farklılıklar önemsiz bulunmuştur. En düşük hidrokarbon+kolesterol ester oran1 \%7.9 ile B75 grubunda, en yüksek hidrokarbon+kolesterol ester oran1 ise \%9.5 ile B150 grubunda görülmüş olmasına rağmen hidrokarbon+kolesterol ester oranı B ilavesinden etkilenmemiştir. Rasyona ilave edilen B'nin serum lipid bileşenlerinden olan polarlipid (\%) üzerine etkisi önemli bulunmuş ve en düşük polarlipid oranı \%14.9 ile B75, en yüksek polarlipid oranı ise \%17.7 ile B150 gruplarında tespit edilmiştir. B150 grubunda polarlipid oranı diğer gruplardan yüksek $(\mathrm{P}<0.05)$ bulunmuştur. Kanatlı hayvan rasyonlarına B ilavesinin Yüksek Performanslı İnce Tabaka Kromatografi (YPİTK) metodu ile serum toplam lipid profilindeki bileşenlerden polarlipid, diaçilgliserol, ve hidrokarbon+kolesterol ester oranlarına etkisinin incelendiği yerli ya da yabancı dilde yayınlanmış herhangi bir çalışmaya rastlanılmadığı için söz konusu parametreler farklı araştırıcıların verileriyle mukayeseli olarak tartışılamamıştır.

Yumurtacı tavuk rasyonlarına ilave edilen $0,50,75$ ve $150 \mathrm{mg} / \mathrm{kg}$ düzeylerindeki B'nin serum lipid bileşenlerinden olan triaçilgliserol (\%) oranlarına etkisi önemli olmuştur. En düşük triaçilgliserol oranı \% $\% 59.3$ ile B150 grubunda, en yüksek triaçilgliserol oranı \%62.9 ile B75 grubunda tespit edilmiştir. Duncan çoklu 
karşılaştırma testine göre B150 grubunun triaçilgliserol oranı diğer gruplardan düşük $(\mathrm{P}<0.05)$ bulunmuştur. Bor'un toplam serum lipid profili içindeki triaçilgliserol oranına etkisi ile ilgili kanatlı hayvanlarla yapılan herhangi bir çalışmaya rastlanılmamıştır. Ancak, Naghii ve Samman (1993;1997) rat, Eren ve ark. (2006) Japon bıldırcını, Eren ve Uyanık (2007) ile Olgun (2011) yumurtacı tavuk rasyonlarına ilave B'nin serum total trigliserid değerlerini azalttığını; Armstrong ve ark. (2000), domuzlarda B ilavesinin serum trigliserid değerlerini artırdığını; Armstrong and Spears (2001), Mızrak ve Ceylan (2009) ile Şimşek (2011), sırasıyla domuz, yumurtacı tavuk ve etlik piliçlerde trigliserid düzeyinin rasyona $\mathrm{B}$ ilavesinden etkilenmediğini bildirmişlerdir. Yumurtacı tavuk rasyonlarına katılan 0, 50, $75 \mathrm{ve} 150 \mathrm{mg} / \mathrm{kg}$ düzeylerindeki B'nin kolesterol oranı üzerine etkisi önemli $(\mathrm{P}<0.01)$ bulunmuştur. En düşük kolesterol oranı $\% 11.57$ ile B150 grubunda gözlenirken, en yüksek kolesterol oranı \%13.0 ile B0 grubunda olmuştur. Rasyondaki B miktarı arttıkça toplam serum lipid profilindeki kolesterol oranı önemli derecede azalmıştır. Mevcut çalı̧̧madan elde edilen sonuçlar, Eren ve ark. (2006) Japon bıldırcını; Eren ve Uyanık (2007)'ın yumurtacı tavuklar için bildirdikleri bulgularla paralellik gösterirken; Naghii ve Samman (1997)'in ratlarda, Armstrong ve Spears (2001)'in domuzlarda, Mızrak ve Ceylan (2009)'ın damızlık yumurtacı tavuklarda, Kurtoğlu ve ark. (2005)'nın etlik piliçlerde belirlemiş oldukları değerlerden farklı bulunmuştur. Mevcut araştırma bulguları, rasyona ilave edilen B'nin, toplam lipid içindeki kolesterol ve triaçilgliserol oranını düşürme (polar lipid oranını arttırdığı için) ya da değiştirme bakımından etkili olduğunu göstermektedir.

Lipid peroksidasyon değerleri bakımından gruplar arasında meydana gelen farklılıklar önemli bulunmuştur. En düşük lipid peroksidasyon değeri $3.4 \mathrm{nmol} / \mathrm{g}$ doku ile B150 grubunda, en yüksek lipid peroksidasyon değeri ise $3.9 \mathrm{nmol} / \mathrm{g}$ doku ile B50 grubunda olmuştur. B75 ve B150 gruplarının serum lipid peroksidasyonu diğer grupların serum lipid peroksidasyonundan daha $(\mathrm{P}<0.05)$ düşük bulunmuş̧tur. İnce ve ark. (2010), rat diyetlerine $100 \mathrm{mg} / \mathrm{kg} \mathrm{B}$ ilave ederek yaptıkları çalışmada, serum lipid peroksidasyon değerlerinin mevcut çalışmaya benzer şekilde kontrol grubuna kıyasla önemli derecede $(\mathrm{P}<0.01)$ azaldığını bildirmişlerdir. Turkez ve ark. (2007) ise düşük dozlarda $(5-50 \mathrm{mg} / \mathrm{L})$ Bor ilavesinin insan periferik kan kültürlerinde lipid peroksidasyon konsantrasyonunu değiştirmediğini ancak yüksek dozlarda Bor ilavesinin $(500 \mathrm{mg} / \mathrm{L})$ lipid peroksidasyon düzeyini artırdığını bildirmişlerdir. Lipid peroksidasyon düzeyindeki artışın oksidatif stresin önemli bir işareti olduğu göz önüne alındığında (Kim ve ark., 2006), yumurtacı tavuk rasyonlarına 75 ve $150 \mathrm{mg} / \mathrm{kg}$ B ilavesinin lipid peroksidasyon seviyelerinde azalmaya neden olması, aynı zamanda kandaki oksidatif hasara karşı koruyucu bir etkiye sahip olabileceğini de göstermektedir.

Yumurtacı tavuk rasyonlarına farklı seviyelerde ilave edilen B'nin serum protein profili üzerine etkisi önemli bulunmuştur. B'nin farklı protein molekül ağırlıklarına farklı etkisi olmakla birlikte, özellikle albumin, $66,75,161$ ve $186 \mathrm{kDa}$ molekül büyüklüğündeki proteinlerde farkl1lıklar önemli olmuştur. En düşük albumin miktarı $1.094 \mathrm{~g}$ protein/dl ile B0 grubunda iken, en yüksek albumin miktarı $1.181 \mathrm{~g}$ protein/dl ile B75'te tespit edilmiş̧ir. B0 grubu, B50, B75 ve B150 gruplarına göre daha düşük albumin miktarına sahip olmuştur $(\mathrm{P}<0.01)$. En düşük $66 \mathrm{kDa}$ moleküler büyüklükteki protein miktarı $0.240 \mathrm{~g}$ protein/dl ile B0 grubunda iken, en yüksek miktar $0.309 \mathrm{~g}$ protein/dl ile B50 grubunda tespit edilmiştir. B0 grubunun $66 \mathrm{kDa}$ moleküler büyüklükteki protein miktarı B50, B75 ve B150 gruplarından daha düşük bulunmuştur $(\mathrm{P}<0.05) .75 \mathrm{kDa}$ moleküler büyüklükteki protein miktarı en düşük $0.534 \mathrm{~g}$ protein/dl ile B0 grubunda iken, en yüksek $0.655 \mathrm{~g}$ protein ile B50 grubunda olmuştur. B0 grubunda $75 \mathrm{kDa}$ moleküler büyüklükteki protein miktarının B50, B75 ve B150 gruplarından daha düşük olduğu tespit edilmiştir $(\mathrm{P}<0.01)$. Rasyona ilave edilen her düzeydeki $\mathrm{B}$, serum protein profilinde $75 \mathrm{kDa}$ moleküler büyüklükteki proteinin miktarını artırmıştır.

Yumurtacı tavuk rasyonlarına farklı miktarlarda B ilavesinin serum protein bileşimine etkisine ait elektroforetogram analiz sonuçları Şekil 1'de, farklı miktarlarda B içeren rasyonların serum protein profiline etkisi ise Çizelge 4'te verilmiştir. 


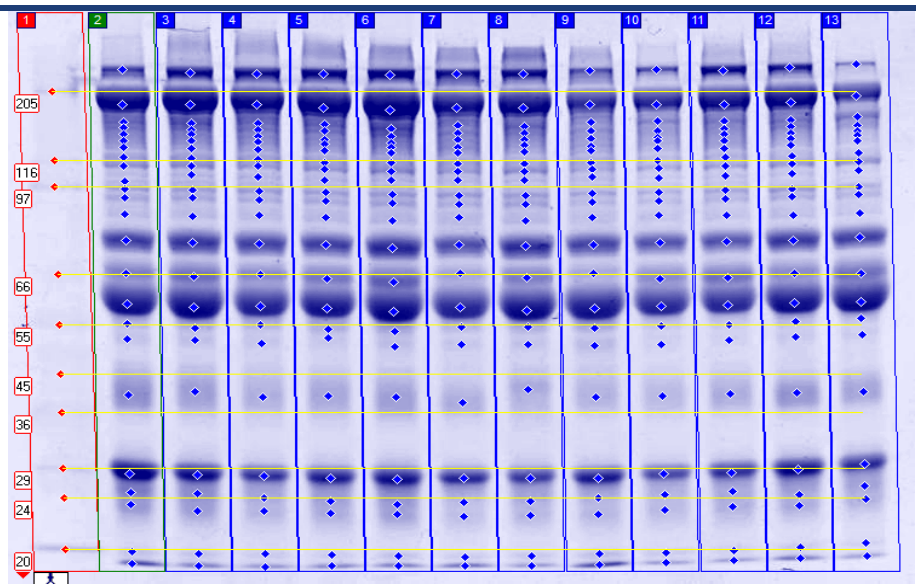

Şekil 1. Serum protein elektroforetogramı

Figure 1. Serum protein electrophoresis

Kuyu: Moleküler ağırlık markeri; 2.-4. Kuyu: Kontrol grubu; 5.-7. Kuyu: B50 grubu; 8.-10. Kuyu: B75 grubu; 11.-13. Kuyu: B150 grubu.

Çizelge 4. Rasyona İlave Edilen Bor (Ortoborik Asit) Seviyelerinin Yumurtacı Tavuklarda Serum Protein Profiline (g/dl) Etkisi

Table 4. Effect of Boron (Ortoboric Acid) Levels Added to Ration on Serum Protein Profile (g/dl) in Laying Hens

\begin{tabular}{|c|c|c|c|c|c|c|}
\hline & & Bor seviyesi, & & & & \\
\hline $\begin{array}{l}\text { Protein } \\
\mathrm{kDa}\end{array}$ & B0 & B50 & B75 & B150 & Ort. & Grup \\
\hline 19 & $0.094 \pm 0.01$ & $0.094 \pm 0.01$ & $0.093 \pm 0.01$ & $0.097 \pm 0.00$ & $0.094 \pm 0.01$ & 0.862 \\
\hline 20 & $0.033 \pm 0.01$ & $0.030 \pm 0.01$ & $0.038 \pm 0.00$ & $0.036 \pm 0.00$ & $0.034 \pm 0.01$ & 0.501 \\
\hline 23 & $0.128 \pm 0.01$ & $0.105 \pm 0.01$ & $0.137 \pm 0.04$ & $0.128 \pm 0.01$ & $0.124 \pm 0.02$ & 0.285 \\
\hline 25 & $0.142 \pm 0.01$ & $0.140 \pm 0.01$ & $0.142 \pm 0.01$ & $0.134 \pm 0.01$ & $0.140 \pm 0.01$ & 0.572 \\
\hline 28 & $0.795 \pm 0.04$ & $0.808 \pm 0.02$ & $0.799 \pm 0.03$ & $0.768 \pm 0.03$ & $0.793 \pm 0.03$ & 0.353 \\
\hline 40 & $0.331 \pm 0.11$ & $0.339 \pm 0.01$ & $0.326 \pm 0.03$ & $0.282 \pm 0.02$ & $0.319 \pm 0.06$ & 0.534 \\
\hline 52 & $0.014 \pm 0.00^{\mathrm{a}}$ & $0.008 \pm 0.00^{\mathrm{b}}$ & $0.015 \pm 0.00^{\mathrm{a}}$ & $0.015 \pm 0.00^{\mathrm{a}}$ & $0.013 \pm 0.00$ & 0.000 \\
\hline 55 & $0.019 \pm 0.00^{\mathrm{b}}$ & $0.021 \pm 0.00^{\mathrm{b}}$ & $0.032 \pm 0.00^{\mathrm{a}}$ & $0.022 \pm 0.00^{\mathrm{b}}$ & $0.024 \pm 0.01$ & 0.011 \\
\hline Alb & $1.094 \pm 0.02^{\mathrm{b}}$ & $1.146 \pm 0.03^{\mathrm{a}}$ & $1.181 \pm 0.03^{\mathrm{a}}$ & $1.170 \pm 0.03^{\mathrm{a}}$ & $1.148 \pm 0.04$ & 0.005 \\
\hline 66 & $0.240 \pm 0.01^{\mathrm{b}}$ & $0.309 \pm 0.03^{\mathrm{a}}$ & $0.285 \pm 0.04^{\mathrm{ab}}$ & $0.283 \pm 0.03^{\mathrm{ab}}$ & $0.279 \pm 0.04$ & 0.034 \\
\hline 75 & $0.534 \pm 0.03^{\mathrm{b}}$ & $0.655 \pm 0.02^{\mathrm{a}}$ & $0.619 \pm 0.04^{\mathrm{a}}$ & $0.649 \pm 0.02^{\mathrm{a}}$ & $0.614 \pm 0.06$ & 0.000 \\
\hline 84 & $0.025 \pm 0.01^{\mathrm{ab}}$ & $0.033 \pm 0.01^{\mathrm{a}}$ & $0.026 \pm 0.01^{\mathrm{ab}}$ & $0.019 \pm 0.00^{\mathrm{b}}$ & $0.026 \pm 0.01$ & 0.031 \\
\hline 91 & $0.038 \pm 0.01$ & $0.036 \pm 0.01$ & $0.041 \pm 0.02$ & $0.041 \pm 0.00$ & $0.039 \pm 0.01$ & 0.922 \\
\hline 96 & $0.045 \pm 0.002$ & $0.50 \pm 0.01$ & $0.048 \pm 0.01$ & $0.048 \pm 0.01$ & $0.047 \pm 0.01$ & 0.861 \\
\hline 100 & $0.009 \pm 0.00^{\mathrm{a}}$ & $0.004 \pm 0.00^{\mathrm{c}}$ & $0.007 \pm 0.00^{\mathrm{b}}$ & $0.006 \pm 0.00^{\mathrm{ab}}$ & $0.007 \pm 0.00$ & 0.003 \\
\hline 111 & $0.055 \pm 0.01$ & $0.064 \pm 0.00$ & $0.059 \pm 0.01$ & $0.056 \pm 0.01$ & $0.058 \pm 0.01$ & 0.527 \\
\hline 119 & $0.043 \pm 0.01^{\mathrm{a}}$ & $0.025 \pm 0.00^{\mathrm{b}}$ & $0.020 \pm 0.01^{\mathrm{b}}$ & $0.019 \pm 0.00^{\mathrm{b}}$ & $0.027 \pm 0.01$ & 0.006 \\
\hline 129 & $0.020 \pm 0.00$ & $0.019 \pm 0.00$ & $0.022 \pm 0.01$ & $0.022 \pm 0.01$ & $0.021 \pm 0.00$ & 0.854 \\
\hline 137 & $0.047 \pm 0.01$ & $0.040 \pm 0.00$ & $0.039 \pm 0.00$ & $0.039 \pm 0.01$ & $0.041 \pm 0.01$ & 0.189 \\
\hline 145 & $0.072 \pm 0.01^{\mathrm{a}}$ & $0.064 \pm 0.01^{\mathrm{ab}}$ & $0.061 \pm 0.01^{\mathrm{ab}}$ & $0.051 \pm 0.01^{\mathrm{b}}$ & $0.061 \pm 0.01$ & 0.035 \\
\hline 153 & $0.106 \pm 0.02$ & $0.088 \pm 0.00$ & $0.092 \pm 0.01$ & $0.087 \pm 0.00$ & $0.093 \pm 0.01$ & 0.104 \\
\hline 161 & $0.100 \pm 0.00^{\mathrm{b}}$ & $0.116 \pm 0.01^{\mathrm{ab}}$ & $0.124 \pm 0.01^{\mathrm{a}}$ & $0.123 \pm 0.01^{\mathrm{a}}$ & $0.116 \pm 0.01$ & 0.041 \\
\hline 186 & $1.036 \pm 0.06^{\mathrm{a}}$ & $1.092 \pm 0.04^{\mathrm{a}}$ & $0.930 \pm 0.02^{\mathrm{b}}$ & $0.920 \pm 0.03^{\mathrm{b}}$ & $0.994 \pm 0.08$ & 0.000 \\
\hline \multirow[t]{2}{*}{233} & $0.431 \pm 0.06$ & $0.464 \pm 0.01$ & $0.447 \pm 0.03$ & $0.437 \pm 0.04$ & $0.445 \pm 0.04$ & 0.649 \\
\hline & $5.45 \mathrm{~g} / \mathrm{dl}$ & $5.75 \mathrm{~g} / \mathrm{dl}$ & $5.58 \mathrm{~g} / \mathrm{dl}$ & $5.45 \mathrm{~g} / \mathrm{dl}$ & & \\
\hline
\end{tabular}

a,b,c; Aynı satırdaki farklı harfle gösterilen ortalamalar arasındaki fark önemlidir.

$161 \mathrm{kDa}$ moleküler büyüklükteki proteinin en düşük miktarı $0.100 \mathrm{~g}$ protein/dl ile B0 grubunda iken, en yüksek miktarı $0.124 \mathrm{~g}$ protein/dl ile B75 grubunda belirlenmiştir. B0 grubunun $161 \mathrm{kDa}$ büyüklüğündeki protein miktarı B50, B75 ve B150 gruplarından düşük bulunmuştur $(\mathrm{P}<0.05)$. Rasyona ilave edilen her 
düzeydeki B'nin serum protein profilinde $161 \mathrm{kDa}$ moleküler büyüklükteki protein miktarının önemli $(\mathrm{P}<0.05)$ derecede artmasına neden olmuştur. $186 \mathrm{kDa}$ büyüklüğündeki protein molekülünün en düşük miktarı $0.920 \mathrm{~g}$ protein/dl ile B150 grubunda, en yüksek miktarı $1.092 \mathrm{~g}$ protein/dl ile B50 grubunda tespit edilmiştir. B0 ve B50 gruplarında $186 \mathrm{kDa}$ moleküler büyüklükteki proteinin miktarı B75 ve B150 gruplarından yüksek bulunmuş $(\mathrm{P}<0.01)$ ve rasyonda artan $\mathrm{B}$ seviyesi $186 \mathrm{kDa}$ moleküler büyüklükteki proteinin miktarını azaltmıştır. Kanatlı hayvan rasyonlarına B ilavesinin SDS-PAGE metodu ile serum protein profiline etkisinin incelendiği yerli ya da yabancı dilde yayınlanmış herhangi bir çalışmaya rastlanılmadığı için mevcut çalışmadan elde edilen sonuçlar arzu edilen düzeyde tartışılamamıştır.

Sonuç olarak, yumurtlamanın son döneminde bulunan tavukların rasyonlarına değişik miktarlarda B ilavesinin serum lipid bileşimi ve peroksidasyonu ile protein miktarını önemli derecede etkilediğinin tespit edilmesinin yanı sıra serum parametreleri üzerine B ilavesinin etkisini açıklığa kavuşturmak için konu ile ilgili daha fazla araştırma yapılması gerektiği kanaatine varılmıştır.

\section{Teşekkür}

2009/213 proje numarasıyla Atatürk Üniversitesi BAP komisyonu tarafından desteklenen ve Prof. Dr. Muhlis MACİT danışmanlığında Hacer KAYA tarafından hazırlanan Doktora Tezinden özetlenmiş olan bu çalışma, 25 - 27 Nisan 2018 tarihleri arasında, Harran Üniversitesi Ziraat Fakültesi bünyesinde gerçekleştirilen 1. Uluslararası GAP Tarım ve Hayvancılık Kongresi’nde sözlü olarak sunulmuştur. 


\section{Kaynakça/References}

Ammerman, C.B., D.H. Baker and A.S. Lewis, 1995. Biovailibility of Nutrients for Animals: Amino Acid, Minerals and Vitamins. Academic Pres. San Diego. CA.

AOAC., 1990. Official methods of analysis. Vol.1. 15 ${ }^{\text {th }}$ ed. Assoc. Off. Anal. Chem., Arlington, VA.

Armstrong, T.A., J.W. Spears, T.D. Crenshaw and F.H. Nielsen, 2000. Boron supplementation of a semipurified diet for weanling pigs improves feed efficiency and bone strength characteristics and alters plasma lipid metabolites. The Journal of nutrition,130 (10): 2575 2581 .

Armstrong, T.A. and J.W. Spears, 2001. Effect of dietary boron of growth performance, calcium and phosphorus metabolism, and bone mechanical properties in growing barrows. Journal of animal science, 79(12): 3120-3127.

Duncan, D.B. 1995. Multiple range and multiple F tests. Biometrics, 11: 1-42.

Eren, M. 2004. Bor’un biyolojik önemi ve metabolizma üzerine etkileri. Erciyes Üniversitesi Veteriner Fakültesi Dergisi, 1(1):55-59.

Eren, M., F. Uyanık and S. Küçükersan, 2004. The influence of dietary boron supplementation on egg quality and serum calcium, inorganic phosphorus, magnesium levels and alkaline phosphatase activity in laying hens. Research in veterinary science,76(3): 203-210.

Eren, M., G.B. Kocaoğlu, Uyanık F. and N. Karabulut, 2006. The effect of dietary boron supplementation on performance, carcass composition nad serum lipids in japanase quails. Journal Of Anımal And Veterınary Advances, 5 (12):1105-1108.

Eren, M. and F. Uyanık, 2007. Influence of dietary boron supplmentation on some metabolietes and egg-yolk cholesterol in laying hens. Acta Veterinaria Hungarica, 55 (1):29-39.

Forbes, R.M., 1984. Use of Labaratory Animals to Define phsyiological functions and biovailbility of zinc. In Federation proceedings, 43(13):2835-2841.

Hunt, C.D., 1989. Dietary boron modified the effects of magnesium and molybdenum on mineral metabolism in the cholecalciferol-deficient cick. Biological trace element research, 22(2):201-220.

Hunt, C.D. and J.L. Herbel, 1991. Boron affects energy metabolism in the streptozotocin-injected, vitamin D3-deprived rat. Magnesium and trace elements, 10:374-386.

Hunt, C.D., J.L. Herbel and F.H. Nielsen, 1991. Dietary boron modifies the effects of Vitamin D3 nutrition on indices of energy substrate utilisation and mineral metabolism in the chick. Journal of bone and mineral research, 9(2):171-182.

Hunt, C.D. 2006. Dietary boron: Progress in establishing essential roles in human and animal physiology. III. Uluslararası Bor Sempozyumu. s: 3-10, 2-4 Kasim, Ankara.

Ince, S., I. Kucukkurt, I.H. Ciğerci, A.F. Fidan and A. Eryavuz, (2010). The effects of dietary boric acid and borax supplementation on lipid peroxidation, antioxidant activity, and DNA damage in rats. Journal of Trace Elements in Medicine and Biology, 24(3):161-164.

Kim, H., E. Oh, H. Im, J. Mun, M. Yang, J.Y. Khim and D. Sul, (2006). Oxidative damages in the DNA, lipids, and proteins of rats exposed to isofluranes and alcohols. Toxicology, 220(2):169-178.

Kurtoğlu, F., V. Kurtoğlu, İ. Çelik, T. Keçeci and M. Nizamlığlu, 2005. Effect of dietary boron supplementation on some biochemical parameters, peripheral blood lymphocytes, splenic plasma cells and bone characteristics of brolier chicks given diets with adequate or inadequate cholecalciferol (vitamin D3) content. British poultry science, 46 (1):87- 96.

Laemmli, U.K. 1970. "Cleavage of structural proteins during the assemble head of $\quad$ bacterophage T4," Nature, 227 (5259):680-685.

Lowry, O.H., N.J. Rosebrough, A.L. Farr and R.J. Randall, 1951. "Protein measurement with folin phenol reagent," Journal of biological chemistry, 193:265-275.

Mertens, D. 2005. AOAC Official Method 975.03.Metal in Plants and Pet Foods. Official Methods of Analysis, $18^{\text {th }}$ edit. Horwitz, W., and G.W. Latimer, (Eds).Chapter 3, pp 3-4, AOAC- International Suite 500, 481. North Frederick Avenue, Gaitherburg, Maryland 208772417, USA.

Mızrak, C. and M. Ceylan, 2009. Damızlık yumurtacı tavuk yemlerine farklı seviye ve formda bor ilavesinin performans, kemik gelişimi ve bazı kan parametreleri üzerine etkisi 6.Ulusal Zootekni Bilim Kongresi. 60-69, 24-26 Haziran,Erzurum.

Naghii, M.R. and S. Samman, 1993. The role of boron in nutrition and metabolism. Progress in food \& nutrition science, 17:331-49.

Naghii, M.R. and S. Samman, 1997. The effect of boron on plazma testosterone and plazma lipis in rats. Nutrition Research, 17 (3):523-531.

Nielsen, F.H. 1997. Boron in human and animal nutrition. Plan and Soil, 193, 199-208.

Okuyan, M.R. 1997. Hayvan Besleme Biyokimyası, Ankara Üniversitesi, Ziraat Fakültesi, Yay. No: 1491, Ders kitab1: 450, 350 s, Ankara.

Olgun, O., 2011. Yumurtacı tavuk rasyonlarına farklı seviyelerde ilave edilen bor ve bakırın performans, yumurta kabuk kalitesi, yumurta sarısı kolesterolü ve kemiğin biyomekanik özelliklerine etkisi. Doktora Tezi, Selçuk Üniversitesi, Fen Bilimleri. Enstitüsü, Konya. 
Placer, Z.A., L.L. Cushman and B.C. Johnson, 1966. "Estimation of product of lipid peroxidation (malonyl dialdehyde) in biochemical systems," Analytical biochemistry, 16(2):359-364.

SAS. 1996. SAS Institute Inc., NC, USA

Sherma, J. 2003. Handbook of Thin-Layer Chromatography. $3^{\text {rd }}$ ed. Taylor \& Francis. NewYork.

Şimşek, M. 2011. Etlik piliç rasyonlarına bor (ortoborik asit) ilavesinin performans değerleri ile tibia mineral konsantrasyonu ve bazı kan parametreleri üzerine etkisi. Yüksek Lisans Tezi, Atatürk Üniversitesi, Fen Bilimleri Enstitüsü, Erzurum.

Turkez, H., F. Geyikoğlu, A. Tatar, S. Keleş and A. Özkan, (2007). Effects of some boron compounds on peripheral human blood. Zeitschrift für Naturforschung C, 62(11-12):889-896.

TSE, 1991. "Hayvan Yemleri Metabolik Enerji Tayini," TSE No:9610. Türk Stantdartları Enstitüsü, Ankara.

Underwood, E.J. and N.F. Suttle, 1999. The minerel nutrition of livestock, $3^{\text {rd }}$ ed. CABI Publishing, New York, NY.

Wilson, J.H. and P.L. Ruszler, 1998. Long term effect of boron on layer bone strength and production parameters. British Poultry Science, 39(1):11-15.

Yazgan, O., Y. Cufadar ve O. Olgun, 2007. Hayvan besleme biyokimyası. Basılmamış Ders Notu. Selçuk Üniversitesi, Ziraat Fakültesi, Zootekni Bölümü, Konya.

Yıldız, G., F. Özçelik, H. Koksal, S. Bağder ve Ö. Abacığlu, 2008. Organik bor üretilebilirliği ve broyler rasyonlarında bor ile humatın kullanımı. 2. Ulusal Bor Çalıştayı Bildirileri, 597-604, 17-18 Nisan, Ankara. 